\title{
SYNTHESIS AND PROPERTIES OF LANTHANIDE-EXCHANGED
} PREYSSLER'S HETEROPOLYANIONS

MARK R. ANTONIO, J. MALINSKY, AND L. SODERHOLM

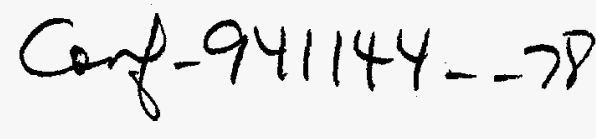

Chemistry Division, Argonne National Laboratory, 9700 S. Cass Avenue, Argonne, IL 60439-4831, USA

\begin{abstract}
$\mathrm{Na}^{+}$in the Preyssler heteropolytungstate anion $\left[\mathrm{NaP}_{5} \mathrm{~W}_{30} \mathrm{O}_{110}\right]^{14-}$ can be exchanged for a trivalent lanthanide ion. The potential significance of this new class of lanthanide heteropolyanions relates to their applications in catalysis science. This view follows from the fact that Keggin heteropolyanions and their free acids are used as heterogeneous solid catalysts and homogeneous solution catalysts. We describe synthetic conditions that lead to the incorporation of $\mathrm{Ce}^{3+}$ and $\mathrm{Pr}^{3+}$ within the Preyssler anion, and the coprecipitation of $\mathrm{Ce}^{3+}$ and the Preyssler anion. Initial studies indicate that the latter, coprecipitated, material deserves study for bifunctional catalytic activity.
\end{abstract}

\section{INTRODUCTION}

Heteropolyanions are discrete clusters, with sizes varying from 50-200 atoms, that can accept substantial reduction in their overall net charge without decomposition. [1-3] As such, these polynuclear anions serve to bridge the gap between the chemistry of small molecular clusters with discrete, atomic-like energy levels, on the one hand, and covalent solids with delocalized, bandlike energy levels, on the other. The prototypical heteropoly oxoanions have the 1:12 Keggin structure, $\left[\mathrm{PM}_{12} \mathrm{O}_{40}\right]^{3-}\left(\mathrm{M} \equiv \mathrm{Mo}^{6+}, \mathrm{W}^{6+}\right)$. Upon electrochemical reduction with one or more electrons, the anion is transformed into an intensely colored, heteropoly blue $\left[\mathrm{PM}_{12} \mathrm{O}_{40}\right]^{\mathrm{n}-}, \mathrm{n}=4,5,6$. In view of their remarkable redox behavior, heteropolyanions have received considerable attention, both experimentally and theoretically, from both academic and industrial research groups. Principal interest stems from the potential technological spin-offs to catalysis science. Heteropolymolybdates and -tungstates, for example, show activity as acid as well as oxidation and ammoxidation catalysts.[3-8] Heteropolyanions and their free acids, i.e., heteropolyacids, are used as both heterogeneous solid catalysts and homogeneous solution catalysts.

Between 1968 and 1971, four new types of heteropolyanion clusters with rare earth $(R E)$ elements were reported:[9-12] (1) decatugstometalates, $\left[R E \mathrm{~W}_{10} \mathrm{O}_{36}\right]^{\mathrm{n}-}$; (2) dodecamolybdometalates, $\left[R E \mathrm{Mo}_{12} \mathrm{O}_{42}\right]^{\mathrm{n}-}$; (3) bis(undecatungsto)metalates $\left[R E\left(\mathrm{PW}_{11} \mathrm{O}_{39}\right)_{2}\right]^{\mathrm{n}-;} ;(4)$ bis(heptadecatungsto)metalates, $\left[R E\left(\mathrm{P}_{2} \mathrm{~W}_{17} \mathrm{O}_{61}\right)_{2}\right]^{\mathrm{n}-}$. Examples of the complexes prepared to date are summarized in Table I. More recently, the preparation of a number of bis(undecatungstocuprate)lanthanates, $\left[R E\left(\mathrm{CuW}_{11} \mathrm{O}_{39}\right)_{2}\right]^{17-}$, as well as the germanium and boron derivatives, $\left[R E\left(\mathrm{GeW}_{11} \mathrm{O}_{39}\right)_{2}\right]^{13-}$ and $\left[R E\left(\mathrm{BW}_{11} \mathrm{O}_{39}\right)_{2}\right]^{15-}$, have been described,[13-14] Table I, Such heteropolyoxometalate clusters containing rare earth ions with dual valence states, such as $\mathrm{Ce}, \mathrm{Pr}, \mathrm{Tb}(3+$ and $4+)$ or $\mathrm{Sm}, \mathrm{Eu}, \mathrm{Tm}, \mathrm{Yb}(2+$ and $3+)$, and multivalent $(3+, 4+, 5+, 6+)$ transition metal ions of Group VIB are of particular interest. These can have unusual redox properties-facile, reversible reductionoxidation - that may be exploited for catalysis. In fact, a recent study described the behavior of $\left[\mathrm{Ce}^{4+} \mathrm{W}_{10} \mathrm{O}_{36}\right]^{8-},\left[\mathrm{Nd}^{3+} \mathrm{W}_{10} \mathrm{O}_{36}\right]^{9-}$, and $\left[\mathrm{Sm}^{3+} \mathrm{W}_{10} \mathrm{O}_{36}\right]^{9-}$ for the homogenous, selective oxidation of cyclohexanol with $\mathrm{H}_{2} \mathrm{O}_{2}$ and for $\mathrm{H}_{2} \mathrm{O}_{2}$ decomposition.[15] 


\section{DISCLAIMER}

This report was prepared as an account of work sponsored by an agency of the United States Government. Neither the United States Government nor any agency thereof, nor any of their employees, makes any warranty, express or implied, or assumes any legal liability or responsibility for the accuracy, completeness, or usefulness of any information, apparatus, product, or process disclosed, or represents that its use would not infringe privately owned rights. Reference herein to any specific commercial product, process, or service by trade name, trademark, manufacturer, or otherwise does not necessarily constitute or imply its endorsement, recommendation, or favoring by the United States Government or any agency thereof. The views and opinions of authors expressed herein do not necessarily state or reflect those of the United States Government or any agency thereof. 


\section{DISCLAIMER}

Portions of this document may be illegible in electronic image products. Images are produced from the best available original document. 
Table I. Rare-earth $(R E)$ element-containing heteropolyanions with the cluster charge (n) and the $R E$ ions reported to form these structures.

\begin{tabular}{|ccl|}
\hline Heteropolyanion & Charge $(\mathrm{n})$ & $R E$ \\
\hline$\left[R E \mathrm{~W}_{10} \mathrm{O}_{36}\right]^{\mathrm{n}-}$ & 9 & $3+(\mathrm{Y}, \mathrm{La}-\mathrm{Yb})$ \\
& 8 & $4+(\mathrm{Ce}, \mathrm{Th}, \mathrm{U})$ \\
{$\left[R E \mathrm{Mo}_{12} \mathrm{O}_{42}\right]^{\mathrm{n}-}$} & 9 & $3+(\mathrm{Ce})$ \\
& 8 & $4+(\mathrm{Ce}, \mathrm{Th}, \mathrm{U}, \mathrm{Np})$ \\
{$\left[R E\left(\mathrm{PW}_{11} \mathrm{O}_{39}\right)_{2}\right]^{\mathrm{n}-}$} & 7 & $5+(\mathrm{U})$ \\
& 11 & $3+(\mathrm{La}, \mathrm{Ce}, \mathrm{Pr}, \mathrm{Nd}, \mathrm{Gd})$ \\
& 10 & $4+(\mathrm{Ce}, \mathrm{U})$ \\
{$\left[R E\left(\mathrm{SiW}_{11} \mathrm{O}_{39}\right)_{2}\right]^{\mathrm{n}-}$} & 9 & $5+(\mathrm{U})$ \\
& 13 & $4+(\mathrm{Ce}, \mathrm{Sm}, \mathrm{Eu}, \mathrm{Tb}, \mathrm{Ho})$ \\
& 12 & $5+(\mathrm{U})$ \\
{$\left[R E\left(\mathrm{CuW}_{11} \mathrm{O}_{39}\right)_{2}\right]^{\mathrm{n}-}$} & 11 & $3+(\mathrm{La}-\mathrm{Gd}, \mathrm{Dy}, \mathrm{Ho}, \mathrm{Yb})$ \\
{$\left[R E\left(\mathrm{P}_{2} \mathrm{~W}_{17} \mathrm{O}_{61}\right)_{2}\right]^{\mathrm{n}-}$} & 17 & $3+(\mathrm{Ce}, \mathrm{Tb}, \mathrm{Dy}, \mathrm{Ho})$ \\
{$\left[R E \mathrm{Sb}_{9} \mathrm{~W}_{21} \mathrm{O}_{86}\right]^{\mathrm{n}-}$} & 17 & $4+(\mathrm{Ce}, \mathrm{Tb}, \mathrm{Th}, \mathrm{U})$ \\
{$\left[R E \mathrm{P}_{5} \mathrm{~W}_{30} \mathrm{O}_{110}\right]^{\mathrm{n}-}$} & 16 & $3+(\mathrm{La}-\mathrm{Gd}, \mathrm{Dy}, \mathrm{Yb})$ \\
& 16 & $3+(\mathrm{Y}, \mathrm{Nd}-\mathrm{Lu})$ \\
& 12 & $4+(\mathrm{U})$ \\
\hline
\end{tabular}

Among the large number and variety of heteropolyoxolanthanate clusters, it is most common that lacunary (i.e., unsaturated) polyanions act as ligands for the $R E$ ions. In contrast, there are just two heteropolyanions of composition $\left[\mathrm{NaSb}_{9} \mathrm{~W}_{21} \mathrm{O}_{86}\right]^{18-}$ and $\left[\mathrm{NaP}_{5} \mathrm{~W}_{30} \mathrm{O}_{110}\right]^{14-}$ that encapsulate rare earth ions through $\mathrm{Na}^{+}$exchange, $[16,17]$ the latter of which is known as the Preyssler anion, PA. A single-crystal X-ray structure study reveals that it contains $\mathrm{Na}^{+}$within a central cylindrical cavity formed by the cyclic arrangement of five $-\mathrm{PW}_{6} \mathrm{O}_{22}$ - groups assembled with $\mathrm{D}_{5 \mathrm{~h}}$ symmetry.[18] Under relatively rigorous conditions, $\mathrm{Na}^{+}$can be exchanged with $R E^{3+}(R E \equiv \mathrm{Y}, \mathrm{Nd}-\mathrm{Lu})$ to form heteropolyoxotungstate anions $\left[R E \mathrm{P}_{5} \mathrm{~W}_{30} \mathrm{O}_{110}\right]^{12-}$.[17] The significance and interest of these $R E$-exchanged heteropolyanions relates to their possible utilization in separation and catalysis sciences. For example, the cavity through the Preyssler anion bears some resemblance to the tunnels connecting cages in microporous aluminophosphate molecular sieves and zeolites. In view of this, $R E$-ion exchanged Preyssler anions may have properties in common with $R E$-ion exchanged zeolites, which are in widespread use as hydrocarbon cracking catalysts and may have some impact on the catalytic reduction of NO.[19] The catalytic efficiency of the Preyssler anion for the selective oxidation of $\mathrm{H}_{2} \mathrm{~S}$ by molecular oxygen in aqueous solution was the subject of a recent investigation by Harrup and Hill.[20]

This report describes new preparative chemistry for the exchange of $\mathrm{Na}^{+}$in $\left[\mathrm{NaP}_{5} \mathrm{~W}_{30} \mathrm{O}_{110}\right]^{14-}$ with $\mathrm{Ce}^{3+}$ and $\mathrm{Pr}^{3+}$. We have also performed initial studies on the coprecipitation of $\mathrm{Ce}^{3+}$ and the Preyssler anion. The motivation for study of the latter PA-supported $\mathrm{Ce}^{3+}$ complex stems from the preparation of rhodium and iridium polyoxometalates of $\left[\mathrm{SiW}_{12} \mathrm{O}_{40}\right]^{4-}$ and $\left[\mathrm{PMo}_{12} \mathrm{O}_{40}\right]^{3-}$. These have been described as bifunctional catalysts with diverse reaction chemistry, including olefin isomerization, hydrogenation, hydroformylation, and $\mathrm{C}-\mathrm{H}$ activation processes.[21] Similarly, polyoxoanion-supported iridium and ruthenium (pre)catalysts have been prepared and characterized.[22,23] The cyclic voltammetry (CV) and $R E \mathrm{~L}_{3}$-edge XANES (X-ray 
absorption near edge structure) of $\left[R E \mathrm{P}_{5} \mathrm{~W}_{30} \mathrm{O}_{110}\right]^{12-}$ and the $\mathrm{Ce}^{3+}$ salt of $\left[\mathrm{NaP}_{5} \mathrm{~W}_{30} \mathrm{O}_{110}\right]^{14-}$ are described herein.

\section{EXPERIMENTS}

The white, crystalline Preyssler salt, $\mathrm{K}_{12.5} \mathrm{Na}_{1.5}\left[\mathrm{NaP}_{5} \mathrm{~W}_{30} \mathrm{O}_{110}\right] \cdot 15 \mathrm{H}_{2} \mathrm{O}$, was prepared according to the method of ref 17 . The $\mathrm{Ce}^{3+}$ and $\mathrm{Pr}^{3+}$-exchange reactions were based upon the following equation:

$$
\left[\mathrm{NaP}_{5} \mathrm{~W}_{30} \mathrm{O}_{110}\right]^{14-}+\mathrm{n} R E^{3+} \longrightarrow\left[R E \mathrm{P}_{5} \mathrm{~W}_{30} \mathrm{O}_{110}\right]^{12-}+(\mathrm{n}-1) R E^{3+}+\mathrm{Na}^{+}
$$

In a typical experiment for $\mathrm{n}=1$, a colorless warm $\left(60^{\circ} \mathrm{C}\right)$ solution of $\mathrm{Ce}\left(\mathrm{NO}_{3}\right)_{3} \cdot 6 \mathrm{H}_{2} \mathrm{O}(53$ $\mathrm{mg}, 0.121 \mathrm{mmole}$, dissolved in $3 \mathrm{~cm}^{3}$ of $\mathrm{H}_{2} \mathrm{O}$ ) was added dropwise with stirring to a warm $\left(60^{\circ} \mathrm{C}\right)$ solution of the Preyssler salt $\left(1 \mathrm{~g}, 0.121 \mathrm{mmol}\right.$, dissolved in $\left.12 \mathrm{~cm}^{3} \mathrm{H}_{2} \mathrm{O}\right)$. The resulting clear, colorless solution was sealed in a Parr 4746 Teflon-lined digestion vessel and heated at $165^{\circ} \mathrm{C}$ in a Lindberg/Blue $\mathrm{M}$ crucible furnace for $48 \mathrm{~h}$. Upon cooling, $4 \mathrm{~g}$ of solid $\mathrm{KCl}$ was added to the clear yellow solution to precipitate a fine pale yellow powder, which was collected on No. 42 Whatman filter paper, rinsed with ca. 10 $\mathrm{cm}^{3}$ of ice-cold water and dried in air. The same procedure was followed for $\mathrm{n}=2$ in the equation above. Yields of $0.86-0.98 \mathrm{~g}\left(80-90 \%\right.$ based upon $\left[\mathrm{NaP}_{5} \mathrm{~W}_{30} \mathrm{O}_{110}\right]^{14-}$ and an estimated empirical formula $\mathrm{K}_{12}\left[\mathrm{CeP}_{5} \mathrm{~W}_{30} \mathrm{O}_{110}\right] \cdot 54 \mathrm{H}_{2} \mathrm{O}$ ) were obtained. The $\mathrm{Ce}^{3+}$ exchange reaction occurs with both one and two equivalents of $\mathrm{Ce}^{3+}$ as either $\mathrm{Ce}\left(\mathrm{NO}_{3}\right)_{3} \cdot 6 \mathrm{H}_{2} \mathrm{O}$ or $\mathrm{CeCl}_{3} \cdot 7 \mathrm{H}_{2} \mathrm{O}$. The exchange of $\mathrm{Na}^{+}$with $\mathrm{Pr}^{3+}$ also occurs in aqueous solutions of $\operatorname{Pr}\left(\mathrm{NO}_{3}\right)_{3} \cdot 6 \mathrm{H}_{2} \mathrm{O}$ using the conditions described above. After heating at $165^{\circ} \mathrm{C}$ for $48 \mathrm{~h}$, the clear colorless solution is worked up to produce a white powder.

The following method was used to coprecipate $\mathrm{Ce}^{3+}$ with $\left[\mathrm{NaP}_{5} \mathrm{~W}_{30} \mathrm{O}_{110}\right]^{14-}$. A clear, colorless aqueous solution conatining $\mathrm{Ce}\left(\mathrm{NO}_{3}\right)_{3} \cdot 6 \mathrm{H}_{2} \mathrm{O}(\mathrm{n}=2)$ and the Preyssler salt (prepared exactly as above) was evaporated to dryness at $135^{\circ} \mathrm{C}$ for $2 \mathrm{~h}$ in a drying oven. This coprecipitation produced a pastel yellow solid.

$\mathrm{Ce}$ and $\mathrm{Pr} \mathrm{L} \mathrm{L}_{3}$-edge XANES data were collected at ambient temperature on beam line 4-3 (using a $\mathrm{Si}<220>$ double crystal monochromator) at SSRL and line X-23A2 (using a $\mathrm{Si}<311>$ double crystal monochromator) at NSLS. The vertical entrance slit width was set to $1 \mathrm{~mm}$. The fluorescence signal, $\mathrm{I}_{\mathrm{f}}$, was detected by use of an ion chamber fluorescent detector (The EXAFS Co.) filled with argon and without a fluorescence filter. The powder samples were mounted at the conventional $45^{\circ}$ incident$45^{\circ}$ exit configuration in a helium purged sample box. Nitrogen was used to monitor the incident X-ray intensity, $\mathrm{I}_{0}$. Due to the low concentrations of Ce and Pr, ca. $1.6 \mathrm{wt} \%$, in the exchanged Preyssler anions, the fluorescence XANES, $I_{\mathrm{f}} / \mathrm{I}_{0}$, is not vitiated by selfabsorption effects. The XANES data for the model compounds were obtained by the electron-yield, $\mathrm{I}_{\mathrm{e}} / \mathrm{I}_{0}$, method. The normalization of the X-ray absorption data to a unit edge jump was performed according to conventional methods.[24]

Cyclic voltammetry data were obtained with a BAS $100 \mathrm{~B} / \mathrm{W}$ electrochemical analyzer, a BAS C-2 voltammetry cell stand, and BAS electrodes: $3.0 \mathrm{~mm}$ diameter glassy carbon working electrode (MF-2012); platinum wire auxiliary electrode (MW1032); $\mathrm{Ag} / \mathrm{AgCl}$ reference electrode with vycor tip (MF-2063). The electrolyte (1 M $\mathrm{H}_{2} \mathrm{SO}_{4}$ ) was prepared from $99.9999 \% \mathrm{H}_{2} \mathrm{SO}_{4}$ (Alfa) and $18 \mathrm{M} \Omega-\mathrm{cm}$ water from a Millipore MILLI-QTM water system. CV scans of the neat electrolyte, which was sparged and blanketed with nitrogen, did not reveal any evidence of electroactive impurities in the potential windows of interest, -0.60 to $0.20 \mathrm{~V}$ vs. $\mathrm{Ag} / \mathrm{AgCl}$. The scan rates were $-100 \mathrm{mV} / \mathrm{s}$ and the anion concentrations were ca. $1 \mathrm{mM}$. 


\section{RESULTS AND DISCUSSION}

The CVs of the $\mathrm{Ce}^{3+}$ - and $\mathrm{Pr}^{3+-}$ exchanged Preyssler anions are identical. As shown in Figure 1 for $\left[\mathrm{CeP}_{5} \mathrm{~W}_{30} \mathrm{O}_{110}\right]^{12-}$, the $\mathrm{CV}$ data exhibit 5 reversible redox waves attributable to $\mathrm{W}(6+/ 5+)$ and the formation of heteropoly blues. For comparison, the CV for the parent Preyssler anion is also shown in Figure 1. The differences in the CVs between the $R E^{3+}$-exchanged anions and the parent anion serve to confirm the exchange of $\mathrm{Na}^{+}$with $\mathrm{Ce}^{3+}$ and $\mathrm{Pr}^{3+}$. In fact, the $\mathrm{CVs}$ for the $\mathrm{Ce}^{3+}$ - and $\mathrm{Pr}^{3+}$-exchanged anions shown here are identical to the CVs for all the other $R E^{3+}$-exchanged anions, except $\mathrm{Eu}^{3+} \cdot[17,25]$ Figure 1 also shows the $\mathrm{CV}$ for the yellow material obtained by coprecipitation of $\mathrm{Ce}^{3+}$ and $\left[\mathrm{NaP}_{5} \mathrm{~W}_{30} \mathrm{O}_{110}\right]^{14-}$. It has features that are similar to those in the CV of the Preyssler ion itself. Although additional studies are clearly required, the similarities of the CVs suggest that the $\mathrm{Ce}^{3+}$ cations are not interacting in a chemically significant way with the $\left[\mathrm{NaP}_{5} \mathrm{~W}_{30} \mathrm{O}_{110}\right]^{14-}$ anion framework. This situation of noninteracting cations and anions is similar to that exemplified by the bifunctional catalysts $\left[\left(\mathrm{Ph}_{3} \mathrm{P}\right)_{2} \mathrm{Rh}(\mathrm{CO})\right]_{4}\left[\mathrm{SiW}_{12} \mathrm{O}_{40}\right]$ and $\left[\left(\mathrm{Ph}_{3} \mathrm{P}\right)_{2} \mathrm{IrH}_{2}\right]_{3}\left[\mathrm{PMo}_{12} \mathrm{O}_{40}\right] .[21]$

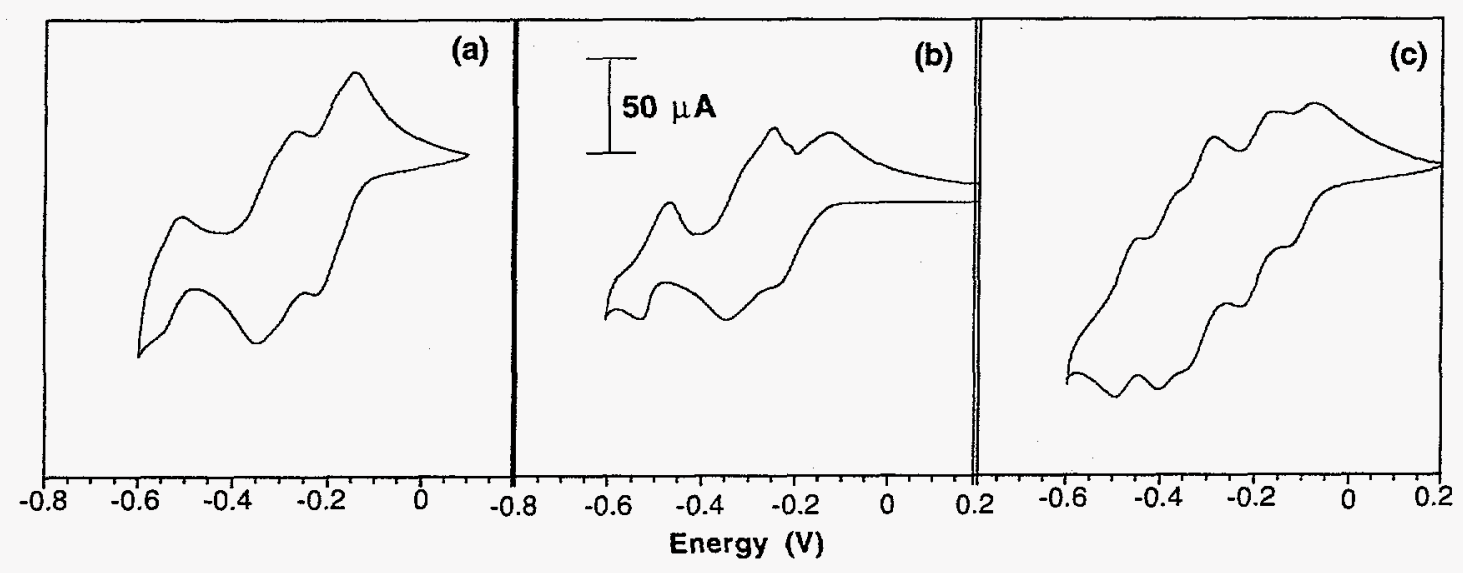

Figure 1. Cyclic voltammograms of (a) $\mathrm{K}_{12.5} \mathrm{Na}_{1.5}\left[\mathrm{NaP}_{5} \mathrm{~W}_{30} \mathrm{O}_{110}\right] \cdot 15 \mathrm{H}_{2} \mathrm{O}$ (b) $\mathrm{K}_{12.5} \mathrm{Na}_{1.5}\left[\mathrm{NaP}_{5} \mathrm{~W}_{30} \mathrm{O}_{110}\right] \cdot 15 \mathrm{H}_{2} \mathrm{O}$ coprecipitated with 2 equivalents of $\mathrm{Ce}\left(\mathrm{NO}_{3}\right)_{3} \cdot 6 \mathrm{H}_{2} \mathrm{O}$ (c) $\mathrm{K}_{12}\left[\mathrm{CeP}_{5} \mathrm{~W}_{30} \mathrm{O}_{110}\right] \cdot \mathrm{nH}_{2} \mathrm{O}$ in aqueous $1 \mathrm{M} \mathrm{H}_{2} \mathrm{SO}_{4}$ electrolytes.

The $\mathrm{Ce}$ and $\mathrm{Pr} \mathrm{L}_{3}$-edge XANES for the solid salts from the Ce and Pr-exchange reactions and the $\mathrm{Ce}$ coprecipitation are shown in Figure 2. The intense single edge resonances at $5721.6 \mathrm{eV}$ (Ce L 3 XANES) and 5965.4 eV ( $\operatorname{Pr~L} \mathrm{L}_{3}$ XANES) are due to $2 p \rightarrow 5 d$ electronic transitions. The edge profiles and positions found here are typical of those observed in $\mathrm{L}_{3}$-edge XANES for trivalent $\mathrm{Ce}$ and $\mathrm{Pr}$ compounds, [26] such as for $\mathrm{Ce}\left(\mathrm{NO}_{3}\right)_{3} \cdot 6 \mathrm{H}_{2} \mathrm{O}$ and $\operatorname{Pr}\left(\mathrm{NO}_{3}\right)_{3} \cdot 6 \mathrm{H}_{2} \mathrm{O}$, see Figure 2. These spectra stand in sharp contrast to the L-edge XANES for compounds containing quadrivalent cerium and 
praseodymium, e.g., $\mathrm{CeO}_{2}$ and $\mathrm{PrO}_{2}$. For such materials, two well-resolved edge resonances are observed.[27] The XANES for the $\mathrm{Ce}^{3+}$-exchanged-PA solid salt shown here is similar to that for the cerium-exchanged PA prepared according to the original method from aqueous $\mathrm{Ce}^{4+}[17]$. In fact, the $\mathrm{Ce}$ XANES for the $\mathrm{K}_{12}\left[\mathrm{CeP}_{5} \mathrm{~W}_{30} \mathrm{O}_{110} \cdot \mathrm{nH}_{2} \mathrm{O}\right.$ solid salt of Figure 2 is identical to that from the aqueous solution of $\left[\mathrm{CeP}_{5} \mathrm{~W}_{30} \mathrm{O}_{110}\right]^{12-}$ prepared from $\mathrm{Ce}^{4+}$. [28] Whereas cerium is trivalent in the exchange products obtained with either $\mathrm{Ce}^{3+}$ or $\mathrm{Ce}^{4+}$ and in view of the fact that the corresponding CV data are identical, the differences between the XANES of the two solid state salts are surprising. They may suggest the presence of a $\mathrm{Ce}^{3+}$ impurity in the original preparations or, alternatively, different locations for $\mathrm{Ce}^{3+}$ within the cylindrical cavity of the Preyssler anion.[28] Additional studies to resolve this issue are in progress.
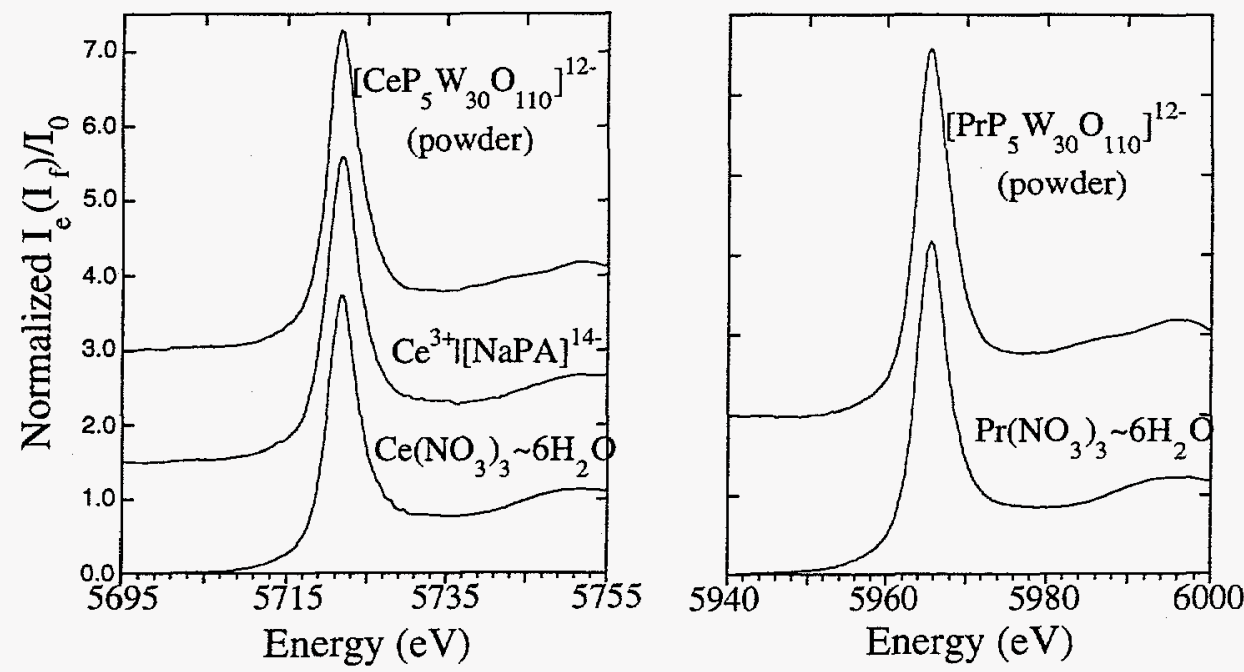

Figure 2. Solid-state $\mathrm{L}_{3}$-edge XANES for (a) $\mathrm{K}_{12}\left[\mathrm{CeP}_{5} \mathrm{~W}_{30} \mathrm{O}_{110}\right] \cdot \mathrm{nH}_{2} \mathrm{O}$, $\mathrm{K}_{12.5} \mathrm{Na}_{1.5}\left[\mathrm{NaP}_{5} \mathrm{~W}_{30} \mathrm{O}_{110}\right] \cdot 15 \mathrm{H}_{2} \mathrm{O}$ coprecipitated with 2 equivalents of $\mathrm{Ce}\left(\mathrm{NO}_{3}\right)_{3} \cdot 6 \mathrm{H}_{2} \mathrm{O}$; $\mathrm{Ce}\left(\mathrm{NO}_{3}\right)_{3} \cdot 6 \mathrm{H}_{2} \mathrm{O}$; (b) $\mathrm{K}_{12}\left[\operatorname{PrP}_{5} \mathrm{~W}_{30} \mathrm{O}_{110}\right] \cdot \mathrm{nH}_{2} \mathrm{O}, \operatorname{Pr}\left(\mathrm{NO}_{3}\right)_{3} \cdot 6 \mathrm{H}_{2} \mathrm{O}$.

\section{CONCLUSIONS}

The exchange of $\mathrm{Na}^{+}$in the Preyssler anion, $\left[\mathrm{NaP}_{5} \mathrm{~W}_{30} \mathrm{O}_{110}\right]^{14-}$, with $\mathrm{Ce}^{3+}$ and $\mathrm{Pr}^{3+}$ was investigated. Under extreme conditions of temperature $\left(165^{\circ} \mathrm{C}\right)$ and time $(48 \mathrm{~h})$, the direct exchange of $\mathrm{Na}^{+}$for $\mathrm{Ce}^{3+}$ and $\mathrm{Pr}^{3+}$ occurs from aqueous solutions of $\mathrm{Ce}\left(\mathrm{NO}_{3}\right)_{3} \cdot 6 \mathrm{H}_{2} \mathrm{O}\left(\right.$ or $\mathrm{CeCl}_{3} \cdot 7 \mathrm{H}_{2} \mathrm{O}$ ) and $\operatorname{Pr}\left(\mathrm{NO}_{3}\right)_{3} \bullet 6 \mathrm{H}_{2} \mathrm{O}$. The Preyssler anion was also precipitated with trivalent cerium. The cyclic voltammetry of the $\mathrm{Ce}$ and $\mathrm{Pr}$ exchange products confirm the $\mathrm{Na}^{+}$ion exchange, and the $\mathrm{L}_{3}$-edge XANES show that $\mathrm{Ce}$ and $\mathrm{Pr}$ are trivalent. Although no catalysis screening studies were performed here, this work provides a new entry to the synthesis of heteropolyanions with potential catalytic activity.

\section{ACKNOWLEDGMENTS}


This work was supported by the U.S. DOE, BES-Chemical Sciences, under contract No. W-31-109-ENG-38.

\section{REFERENCES}

1. M.T. Pope, Heteropoly and Isopoly Oxometalates (Springer-Verlag, Berlin, 1983).

2. M.T. Pope, in Comprehensive Coordination Chemistry, Vol. 3, edited by G. Wilkinson, R.D.Gillard and J.A. McCleverty (Pergamon Press, New York, 1987), pp. 1023-1058.

3. M.T. Pope and A. Müller, Angew. Chem. Int. Ed. Engl. 30, 34 (1991).

4. M. Misono, in Polyoxometalates: From Platonic Solids to Anti-Retroviral Activity, edited by M.T. Pope and A. Müller (Kluwer Academic, Dordrecht, The Netherlands, 1994) pp. 255-265; R.G. Finke, ibid., pp. 267-280; J.H. Grate, D.R. Hamm and S. Mahajan, ibid., pp. 281-305; R. Neumann, ibid., pp. 307-313; E. Cadot, C. Marchal, M. Fournier, A. Teze and G. Herve, ibid., pp. 315-326; E. Papaconstantinou, A. Ioannidis, A. Hiskia, P. Argitis, D. Dimotikali and S. Korres, ibid., pp. 327.335; C.L. Hill, G.-S. Kim, C.M. Prosser-Mccartha and D. Judd, ibid., pp. 359-371.

5. N. Mizuno and M. Misono, J. Molecular Catalysis 86, 319 (1994).

6. M. Misono, Catal. Rev.-Sci. Eng. 29, 269 (1987).

7. I.V. Kozhevnikov and K.I. Matveev, Russian Chemical Reviews 51, 1075 (1982)

8. D. Sattari and C.L. Hill, J. Am. Chem. Soc. 115, 469 (1993)

9. R.D. Peacock and T.J.R. Weakley, J. Chem. Soc. (A) 1971, 1836.

10. P. Baidala, V.S. Smurova, E.A. Torchenkova and V. I. Spitsyn, Doklady Chemistry 197, 430 (1971), Engl. Trans.

11. E.A. Torchenkova, P. Baidala, V.S. Smurova and V.I. Spitsyn, Doklady Chemistry 199, 568 (1971), Engl. Trans.

12. D.D. Dexter and J.V. Silverton, J. Am. Chem. Soc. 90, 3589 (1968).

13. W. Qingyin, W. Enbo and L. Jingfu, Polyhedron 12, 2563 (1993).

14. N. Haraguchi, Y. Okaue, Y. Isobe and Y. Matsuda, Inorg. Chem. 33, 1015 (1994).

15. R. Shiozaki, H. Goto and Y. Kera, Bull. Chem. Soc. Jpn. 66, 2790 (1993).

16. J. Liu, S. Liu, L. Qu, M.T. Pope and C. Rong, Trans. Met. Chem. 17, 311 (1992).

17. I. Creaser, M.C. Heckel, R.J. Neitz and M.T. Pope, Inorg. Chem. 32, 1573 (1993).

18. M.H. Alizadeh, S.P. Harmalker, Y. Jeannin, J. Martin-Frere and M.T. Pope, J. Am. Chem. Soc. 107, 2662 (1985).

19. C. Yokoyama and M. Misono, Bull. Chem. Soc. Jpn. 67, 557 (1994).

20. M.K. Harrup and C.L. Hill, Presented at the 208th National Meeting of the American Chemical Society, Washington, D.C., August 1994; paper INOR 567.

21. A.R. Siedle, R.A. Newmark, W.B. Gleason, R.P. Skarjune, K.O. Hodgson, A.L. Roe and V.W. Day, Solid State Ionics 26, 109 (1988). A.R. Siedle, R.A. Newmark, K.A. Brown-Wensley, R.P. Skarjune, L.C. Haddad, K.O. Hodgson and A.L. Roe, Organometallics 7, 2078 (1988). A.R. Siedle, C.G. Markell, P.A. Lyon, K.O. Hodgson and A.L. Roe, Inorg. Chem. 26, 219 (1987)

22. W.G. Klemperer and B. Zhong, Inorg. Chem. 32, 5821 (1993).

23. Y. Lin, K. Nomiya and R.G. Finke, Inorg. Chem. 32, 6040 (1993)

24. M.R. Antonio, in Encyclopedia of Materials Characterization: Surfaces, Interfaces, Thin Films, edited by C. R. Brundle, C. A. Evans, Jr. and S. Wilson (ButterworthHeinemann, Boston, 1992), p. 214.

25. M.R. Antonio, L. Soderholm, J. Muntean and G. Liu, in preparation (1994).

26. J.E. Sunstrom, IV, S.M. Kauzlarich and M.R. Antonio, Chem. Mater. 5, 182 (1993).

27. Z. Hu, S. Bertram and G. Kaindl, Phys. Rev. B, 49, 39 (1994).

28. M.R. Antonio and L. Soderholm, Inorg. Chem., in the press (1994). 